\title{
Gastric Ulceration, Appetite and Feeding Practices in Standardbred Racehorses in the Czech Republic
}

\author{
B. BEZDĚKOVÁ ${ }^{1}$, P. JAHN ${ }^{1}$, M. VYSKOČIL ${ }^{2}$ \\ ${ }^{1}$ Equine Clinic, Faculty of Veterinary Medicine \\ ${ }^{2}$ Department of Genetics, Faculty of Veterinary Medicine \\ University of Veterinary and Pharmaceutical Sciences, Brno, Czech Republic
}

Received November 15, 2006

Accepted October 1, 2008

\begin{abstract}
Bezděková B., P. Jahn, M. Vyskočil: Gastric Ulceration, Appetite and Feeding Practices in Standardbred Racehorses in the Czech Republic. Acta Vet. Brno 2008, 77: 603-607.

The objective of our study was to determine the prevalence of poor appetite and its correlation with the prevalence of gastric ulceration, and to evaluate relation between feeding management (feeding frequency and feeding regularity) and gastric ulceration in a group of 54 Standardbred racehorses in training. Prevalence of gastric ulceration in the group of horses with poor general appetite was $94.8 \%$. Prevalence of gastric ulceration in the group of horses with good general appetite was $48.6 \%$. Significant association between poor general appetite and squamous gastric ulcer presence was observed $(p<0.001)$. Gastric ulceration was found in $75.0 \%$ of horses fed twice daily and in $57.9 \%$ horses fed three times a day. Fifty seven point nine per cent of regularly fed horses had gastric ulcers. Irregularly fed horses were ulcer-positive in $75.0 \%$. Thus no significant association between feeding frequency or regularity and the occurrence of gastric ulcers was found.
\end{abstract}

Horse, gastric ulcer, training, standardbred, Czech Republic, feed management

Equine gastric ulceration syndrome (EGUS) is highly prevalent in Standardbred racehorses (Rabuffo et al. 2002; Bezděková et al. 2005a; Roy et al. 2005; Jonsson and Egenvall 2006). An increase in aggressive factors including acid content and decreased $\mathrm{pH}$, and a decrease in protective mucosal factors have been confirmed as causes for gastric ulceration in horses (Murray 1991). Although the exact etiology is not clear, factors including stress, feed management, administration of non-steroidal drugs, microbial infection and others are discussed. Previous studies were focused on EGUS occurrence, predisposition and some etiological factors (exercise-accompanied stress) (Bezděková et al. 2005ab; Roy et al. 2005; Jonsson and Egenvall 2006). Jonsson and Egenvall (2006) studied the influence of eating habits on gastric ulceration and did not find a strong relationship.

The first aim of this study was to determine the prevalence of poor appetite and its correlation with gastric ulceration in horses. The second aim of this study was to evaluate the relation between feeding management and gastric ulcers in the same group.

\section{Materials and Methods}

Fifty four 2-year-old and older Standardbred racehorses engaged in routine training and racing were selected for this study. The horses were stalled at 5 trainers. All horses were in active training for at least six months. All horses were examined within the first 10 days after the end of racing season which finishes in the first half of November in the Czech Republic. In each examined horse the intensity of exercise was classified in 4 grades. Grades were set according to the volume of fast work in 1 week, number of racings in 1 month, and the intensity of endurance training. Obtained information was used in a previous study (Bezděková et al. 2005b).

Selected horses were without clinical sings of disease. History was taken and subsequently gastroscopy of squamous gastric mucosa was performed in each horse. None of these horses had taken anti-inflammatory drugs for the period of at least 3 months. Overall prevalence of squamous mucosa ulcers and individual ulcer severity

Address for correspondence:

MVDr. Barbora Bezděková PhD.

Equine Clinic, Faculty of Veterinary Medicine

University of Veterinary and Pharmaceutical Sciences Brno

Palackého 1-3, 61242 Brno

Phone: +420 541562380

E-mail: bbezdekova@vfu.cz

http://www.vfu.cz/acta-vet/actavet.htm 
scores were determined in the monitored group (Bezděková et al. 2005a). Relationship of age, sex and training intensity of the prevalence and severity of gastric ulcers was evaluated (Bezděková et al. 2005b).

The history of feeding habits was taken from each horse. General appetite, feeding frequency and feed regularity were monitored. All horses were fed with oats, non-alfalfa hay (mixed meadow grasses) and commercially available pellets for racing horses. Good general appetite was determined in horses without any partial anorexia episodes within the previous and current racing seasons (for at least 9 months). Poor general appetite was determined in horses showing partial anorexia depending on racing, fast pace work, transportation etc. within the same time. These horses did not finish their grain and hay by the time of the next feeding following previous exercise events. Episodes of partial anorexia occurred more frequently than four times a week. All information was obtained by personal communication with the horse trainer who was in daily contact with the horse. Good general appetite was found in 35 horses $(64.8 \%)$, poor appetite in 19 horses $(35.2 \%)$ (Table 1). Horses were divided into two groups according to feeding frequency (twice or three times per day) and into two groups according to regularity of feeding. Thirty-eight horses $(70.4 \%)$ were fed three times per day, 16 horses $(29.6 \%)$ were fed twice per day (Table 1$)$. Thirty-eight horses $(70.4 \%)$ were fed regularly at the same time of the day with a variation of 30 minutes; 16 horses $(29.6 \%)$ were fed irregularly. The horses fed regularly were also fed three times per a day; the horses fed irregularly were fed two times per a day.

\section{Examination procedure}

Before each gastroscopic examination, food was withheld from the horse for 12 to $16 \mathrm{~h}$ and free access to water was allowed. The horses were sedated with xylazine $(0.3 / 0.5 \mathrm{mg} / \mathrm{kg} \mathrm{IV})$ and the gastric and esophageal mucosa was examined using a 13-mm-diameter, 3.3-m flexible videoendoscope (Dr. Fritz $\left.{ }^{\mathrm{TM}}\right)$. Thorough examination included viewing of the squamous epithelium (nonglandular mucosa), margo plicatus, proximal part of the glandular mucosa and cardia. Pyloric region was not routinely examined because of the presence of fluid residue and gastric peristalsis. An adapted gastric ulcer severity scoring system by Nadeau et al. (2000) was used. Lesions were scored on a scale of $0-4$ :

0 - Intact epithelium with no appearance of hyperaemia or hyperkeratosis (no lesions)

1 - Hyperaemia or hyperkeratosis of mucosa or less than 5 small single lesions

2 - Diffuse damage of mucosa, multifocal lesions with or without hyperkeratosis, more than 5 lesions, no haemorrhage

3 - Multifocal lesions with a loss of surface epithelium and hyperthrophic margins, more than 10 lesions, diffuse damage

4 - Diffuse ulceration of mucosa, loss of margo plicatus continuity, with or without haemorrhage

Statistical analyses

A database was made using the obtained history and gastroscopic examinations. Prevalence data of EGUS were used from the former study (Bezděková et al. 2005a). Occurrence of EGUS was studied in groups divided on the basis of general appetite, feeding frequency and regularity. The obtained results were expressed in percentages. The association between occurrence of gastric ulcers and lack of appetite was analyzed.

The obtained data were statistically analyzed using $\chi^{2}$ (Chi-square test) and its modification for low periodicity (Fisher's test).

\section{Results}

The age of monitored horses varied from 2 to 11 years. The monitored group included 7 two-year-old $(12.96 \%), 11$ three-year-old $(20.37 \%), 9$ four-year old $(16.67 \%), 4$ fiveyear-old $(7.41 \%), 9$ six-year-old $(16.67 \%), 1$ seven-year-old $(1.85 \%), 3$ eight-year-old $(5.56 \%), 2$ nine-year-old $(3.70 \%), 4$ ten-year-old $(7.41 \%)$, and 4 eleven-year-old $(7.41 \%)$ Standardbred horses. The overall prevalence of gastric ulceration in the monitored horses was $62.96 \%$. As can be seen from Table 1, the prevalence of squamous gastric ulceration was $48.6 \%$ (17 horses) in the group of horses with good general appetite and $94.7 \%$ (18 horses) in the group of horses with poor general appetite. Significant association between poor general appetite and EGUS prevalence was observed $(p<0.001)$.

Twelve horses $(75.0 \%)$ fed twice daily had gastric ulcers. Four $(25.0 \%)$ of the horses fed twice daily were EGUS-negative. Twenty-two (57.9\%) horses fed three times per day had gastric ulceration. Sixteen $(42.1 \%)$ of the horses fed three times daily were EGUSnegative. Significant association between feed frequency and EGUS prevalence was not proven. Similarly, 22 of the horses fed regularly presented EGUS (57.9\%). Sixteen horses $(42.1 \%)$ had undisturbed gastric squamous mucosa. Twelve $(75.0 \%)$ irregularly fed horses had gastric ulceration. Four $(25.0 \%)$ of them had no gastric lesions. Significant association between feeding regularity and EGUS prevalence was not found. 
Table 1. Distribution (No.[\%]) of horses with gastric ulcers (EGUS positive) and without gastric ulcers (EGUS negative) according to general appetite, feeding frequency and regularity of feeding in monitored population.

\begin{tabular}{|l|c|c|c|c|}
\hline Variable & & $\begin{array}{c}\text { EGUS positive } \\
\text { No. }(\%)\end{array}$ & $\begin{array}{c}\text { EGUS negative } \\
\text { No. }(\%)\end{array}$ & $\begin{array}{c}\text { Total } \\
\text { No. }(\%)\end{array}$ \\
\hline Appetite & Good & $17(48.6 \%)$ & $18(51.4 \%)$ & $35(64.8 \%)$ \\
\hline & Poor & $18(94.7 \%)$ & $1(5.3 \%)$ & $19(35.2 \%)$ \\
\hline Feeding frequency & $\times 2 /$ day & $12(75.0 \%)$ & $4(25.0 \%)$ & $16(29.6 \%)$ \\
\hline & $\times 3 /$ day & $22(57.9 \%)$ & $16(42.1 \%)$ & $38(70.4 \%)$ \\
\hline Feeding pattern & Regular & $22(57.9 \%)$ & $16(42.1 \%)$ & $38(70.4 \%)$ \\
\hline & Irregular & $12(75.0 \%)$ & $4(25.0 \%)$ & $16(29.6 \%)$ \\
\hline
\end{tabular}

\section{Discussion}

The objective of our study was to determine the association between general appetite, feeding management and gastric ulceration in Standardbred racehorses in the Czech Republic. The prevalence of squamous gastric ulceration was known from the previous study (Bezděková et al. 2005a). Other associations (association of EGUS with age, sex and exercise intensity) were studied previously (Bezděková et al. 2005b).

Prevalence of gastric ulceration in the group of horses examined was $63 \%$. We found neither an association between age or sex and prevalence of ulcers, nor an association between age or sex and severity of gastric ulcers. Significant association was proven between training intensity and occurrence of gastric ulcers. Positive correlation between training intensity and gastric ulceration severity was proven as well (Bezděková et al. 2005ab).

General appetite was good in horses with no changes during the season (observation period of at least 9 months). Poor general appetite was shown in horses with episodes of partial anorexia in dependence on external factors (racing, fast pace work, transportation etc.). Partial anorexia (poor general appetite) is one of the non-specific clinical signs that accompany the syndrome of gastric ulceration in horses (Murray 1992, 1994a; Sanchez 2004). Partial anorexia is usually the first clinical sign noted by the trainer or owner of the affected horse and decreased food intake is strongly associated with lower performance and exercise intolerance. In our study, squamous gastric ulcerations were found in the group of horses with poor general appetite as well as in the group of horses with good general appetite. However, significant association between general appetite and gastric ulceration occurrence was observed. The question remains whether partial anorexia was a consequence of other general disease followed by gastric ulceration, or if it was a consequence of the gastric lesions themselves. Other non-specific clinical signs of EGUS were not studied. Our results show that the loss of appetite appears as a good indicator of gastric ulcers in horses. However, good general appetite is not a guarantee of healthy gastric mucosa. The question is whether the loss of appetite is the cause or the consequence of squamous gastric ulceration. Starvation exceeding $12 \mathrm{~h}$ may cause duodenogastric reflux containing bile acids. Bile acids presence in stomach supports development of squamous gastric ulceration (Kitchen et al. 1998; Berschneider et al. 1999).

Association between feeding frequency twice daily, three times daily and gastric ulcer prevalence was not determined. But the higher number of horses without stomach ulcers in the group fed three times per day shows a possible positive influence of higher feeding frequency on gastric ulcer prevention. Horses fed twice daily had a relatively empty stomach for a longer time in comparison with horses fed three times per day. Permanent gastric juice production and a small gastric volume in horses are factors connected with a frequent feed intake during the day (Campbell-Thompson and Merritt 1987).

Similar results were obtained in the study of association between feed regularity and gastric ulcer presence. Significant association was not confirmed, but the number of EGUS- 
negative horses was higher in the group fed regularly. To our knowledge, relation between feed regularity and gastric ulceration was not studied before.

Feed compound is also an important factor influencing the presence and severity of squamous gastric ulceration. Horses fed with a concentrated diet (low fibre) have higher prevalence and higher severity of EGUS in comparison with horses on pasture (Murray and Schusser 1992; Murray 1994b). In our study, the majority of horses spent some time every day in the paddock, but none of them had access to pasture. Racehorses are usually fed a high concentration diet which is associated with gastric ulceration (Hammond et al. 1986). The horses fed with a concentrated feed show lower gastric $\mathrm{pH}$ (Murray and Schusser 1992; Murray 1994b) and higher serum gastrin concentration (Smyth et al. 1988). We did not obtain exact data on feed composition, gastric $\mathrm{pH}$ or gastrin concentration in our study. Standardbred racehorses are usually fed with high energy diets and hay available in the Czech Republic. We expected small differences in individual diet composition in horses in our study.

\section{Krmný management a žaludeční ulcerace u koní v České republice}

V první části naší studie jsme zjišt'ovali výskyt zhoršeného apetitu u skupiny 54 dostihových klusáků v tréninku a jeho závislost na prevalenci ulcerací žaludku. Dále byl sledován vliv krmného managementu (frekvence krmení, pravidelnost krmení) na výskyt žaludečních ulcerací u stejné skupiny. Prevalence žaludečních ulcerací u skupiny koní se zhoršeným apetitem byla 94,7 \%. Prevalence žaludečních ulcerací u skupiny koní s dobrým apetitem byla $48,6 \%$. U námi sledované skupiny byla prokázána signifikantní závislost mezi výskytem zhoršeného apetitu a výskytem žaludečních ulcerací na skvamózní části sliznice žaludku $(p<0,001)$. Léze žaludeční sliznice byly zjištěny u 75,0 \% koní krmených dvakrát denně a u 57,9 \% koní krmených třikrát denně. Pravidelně krmení koně vykazovali 57,9 \% prevalenci žaludečních ulcerací, nepravidelně krmení koně vykazovali prevalenci žaludečních ulcerací 75,0 \%. U sledované skupiny nebyla prokázána signifikantní závislost mezi krmným managementem a výskytem žaludečních ulcerací.

\section{Acknowledgement}

This study was supported by the VZ MSM 6215712403 Grant of the Czech Republic.

\section{References}

BERSCHNEIDER HM, BLIKSLAGER AT, ROBERTS MC 1999: Role of duodenal reflux in nonglandular gastric ulcer disease of the mature horse. Equine Vet J Suppl: 29: 24-29

BEZDĚKOVÁ B, JAHN P, VYSKOČIL M, PLACHÝ J 2005a: Prevalence of equine gastric ulceration in standardbred racehorses in Czech Republic. Acta Vet Brno 74: 59-65

BEZDĚKOVÁ B, JAHN P, VYSKOČIL M, PLACHÝ J 2005b: Gastric ulceration and exercise intensity in standardbred racehorses in Czech Republic. Acta Vet Brno 74: 67-71

CAMPBELL-THOMPSON ML, MERRITT AM 1987: Effect of ranitidine on gastric acid secretion in young male horses. Am J Vet Res 48: 1511-1515

HAMMOND CJ, MASON DK, WATKINS KL 1986: Gastric ulceration in mature thoroughbred horses. Equine Vet J 18: 284-287

KITCHEN DL, MERRITT AM, BURROW JA 1998: Histamine-induced gastric acid secretion in horses. Am J Vet Res 59: 1303-1306

JONSSON H, EGENVALL A 2006: Prevalence of gastric ulceration in Swedish Standardbreds in race training. Equine Vet J 38:209-13

MURRAY MJ 1991: The pathogenesis and prevalence of gastric ulceration in foals and horses. Vet Med-US 86: 815-819

MURRAY MJ 1992: Gastric ulcerations in horses: 91 cases (1987-1990). J Am Vet Med Assoc 201: 117-120

MURRAY MJ 1994a: Gastric ulcers in adult horses. Compend Contin Educ Pract Vet 16: 792-794

MURRAY MJ 1994b: Equine model of inducing ulceration in alimentary squamous epithelial mucosa. Dig Dis Sci 39: 2530-2535

MURRAY MJ, SCHUSSER G 1992: Application of gastric pH-metry in horses: measurement of 24 hour gastric $\mathrm{pH}$ in horses fed, fasted, and treated with ranitidine. J Vet Intern Med 6: 133 
NADEAU JA, ANDREWS FM, MATJES AG, ARGENZIO RA, BLACKFORD JT, SOHTELL M, SAXTON AM 2000: Evaluation of diet as a cause of gastric ulcers in horses. Am J Vet Res 61: 784-790

RABUFFO TS, ORSINI JA, SULLIVAN E, ENGILES J, NORMAN T, BOSTON R 2002: Associations between age or sex and prevalence of gastric ulceration in standardbred racehorses in training. J Am Vet Med Assoc 221: $1156-1159$

ROY MA, VRINS A, BEAUCHAMP G, DOUCET MY 2005: Prevalence of ulcers of the squamous gastric mucosa in standardbred horses. J Vet Intern Med 19: 744-750

SANCHEZ LC 2004: Diseases of the stomach. In: REED SM, BAYLY WM SELLON DC (Eds): Equine internal medicine, $2^{\text {nd }}$ ed. WB Saunders, Elsevier, pp. 863-873

SMYTH GB, YOUNG DW, HAMMOND LS 1988: Effects of diet and feeding of post-prandial serum gastrin and insulin concentrations in adult horses. Equine Vet J Suppl 7: 56-59 
